\title{
A micro-model of managerial power
}

\author{
Andrew J. Templer \\ School of Business Leadership, University of South Africa, Pretoria
}

In this second article in a series of three on power, the general model of managerial power presented in the first article is expanded to cover the micro-level of power analysis. At this level the focus is upon the interpersonal power relationship between manager and subordinate. It is suggested that a key facet of the micro-model of managerial power is the concept of a psychological contract between manager and employee. It is concluded that management is only able to exercise power to the extent that employees perceive that the terms of their psychological contract have been honoured.

S. Afr. J. Bus. Mgmt. 1980, 11: $75-78$

In hierdie tweede artikel in 'n reeks van drie oor mag, word die algemene model van bestuursmag in die eerste artikel uitgebrei om die mikrovlak van magsontleding in te sluit. Op hierdie vlak val die klem op die interpersoonlike magsverhouding tussen bestuurder en ondergeskikte. Dit word aangevoer dat die begrip van 'n sielkundige kontrak tussen bestuurder en werknemer 'n sleutelfaset is van die mikromodel van bestuursmag. Daar word tot die gevolgtrek. king gekom dat bestuurders alleen in staat is om mag uit te oefen in die mate waarin werkgewers van mening is dat daar aan die terme van hulle sielkundige kontrak gestand gedoen word.

S.Afr. Tydskr. Bedryfs/. 1980, 11:75-78
In an earlier article' the author presented a general model of managerial power in the organization which had as its primary emphasis the macro-analysis of power. It was argued, however, that an adequate conception of managerial power could only be gained through a model which focussed on both the macro and micro levels of analysis. It is therefore the intention of this article to develop the general model of managerial power to include the interpersonal relationship between manager and subordinate. This is the front-line as it were, of the 'power struggle' between manager and subordinate, the level at which it is actually seen whether an employee modifies his behaviour in response to management's wishes.

Why is it necessary to take a power analysis beyond the macro-level of organization structure? Power resulting from position or hierarchy generally favours the manager rather than the subordinate, but is by no means the only power operating within the inter-personal relationship between manager and subordinate. There is considerable power operating in a reverse direction, in other words from subordinate to manager, what Patchen' ${ }^{2}$ terms 'The Power of the Lowerarchy'. It makes sense to conceive not only of manager power bases, but also of subordinate compliance bases which inter-link closely with one another. Another reason why it is necessary to take the analysis beyond structural power is that not all organization participants accept the power as given by the organization structure, that is to many employees this structural power is not seen as legitimate - is not real authority to them. Thus the practical conclusion to be drawn is that in most organizations there is a need for the individual manager to exercise some form of personal power at the inter-personal level, to confirm the structural power in the organization, and perhaps even to overcome serious inadequacies in this structural power.

It makes sense to view managerial power in terms of a balance or exchange relationship in which the strength of a manager's power would lie in the closeness of match between his power base and his subordinate's motivation base. In more simple language, the extent of a manager's power would depend on his offering what his subordinate is wanting in return for compliance with his requests. A useful conception of this exchange relationship, is provided in the concept of the 'Psychological Contract'. This concept is important in the micro-model of managerial power considered below, thus it is sufficient at this point, 


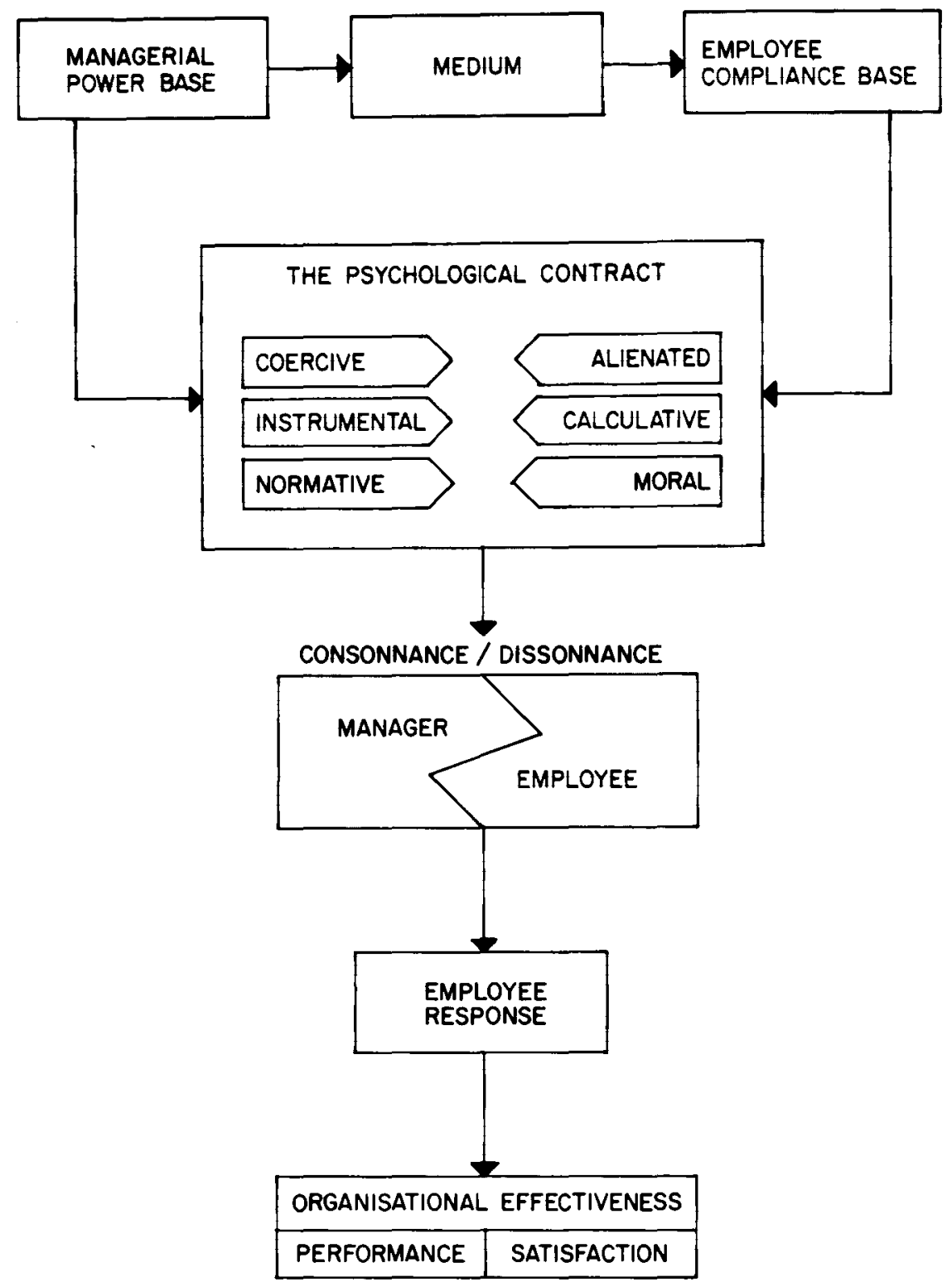

Fig. 1: The micro-model of managerial power

to take note of the usefulness of the concept in analysing the nature of power at the micro-level.

\section{The proposed model}

The proposed model of managerial power at the microlevel is presented in Fig. 1.

It can be seen that this model links into the general model of managerial power described previously ${ }^{\prime}$, and is an expansion of that model to include the interpersonal power process between manager and subordinate. The primary power flow is based on the conception of Tedeschi ${ }^{3}$ and Jackson and Morgan ${ }^{4}$ in terms of which power is seen to flow from a source to a target by means of some sort of method or medium. These authors do not specify who is the source: manager or subordinate, since power being an exchange relationship, could flow in either direction. While it is accepted that power can flow in both directions, since the main focus of this investigation is upon managerial power, the model assumes a flow from manager to subordinate. It can be seen that the micromodel of managerial power is an expansion of the overall model of managerial power in that the psychological contract is now presented in terms of the Etzionis ${ }^{5}$ conception of this contract.
In terms of Pollard and Mitchell ${ }^{5}$ the model presented here falls primarily within the process rather than the outcome theory viewpoint. Process theories emphasize the process by which power is exercised, whereas outcome theories emphasize the end state of a power relationship. While the model does mention outcome in the form of employee response and organizational effectiveness, the primary focus is on process.

It should be pointed out that in terms of the model the distinction between management power base, medium and employee compliance base, is primarily an analytical one, for in reality there is an overlap between the three. Thus for example, it is really only possible to observe the power base of management in terms of the type of medium management chooses for the expression of their power. Similarly the reason why an employee complies with management power may be closely associated with characteristics of the manager, and so it might actually make more sense in certain cases to analyse the employee compliance base in terms of managerial characteristics.

Finally it should not be forgotten that the micro-model of managerial power is but a part of the wider model of managerial power, that is the inter-personal expression of power takes place within a system and is part of a wider 
context. Having introduced the model, attention is now turned to a brief examination of each area of the model, beginning with the bases of managerial power.

\section{The bases of managerial power}

The model suggests that a key variable within the power relationship between manager and subordinate is the base from which the manager chooses to exercise his power. A large number of typologies of managerial power have been developed. No attempt will be made to outline all these typologies, but just an indication will be given of the range of available alternatives.

Reviews $^{6,7}$ of the available typologies suggest that basically two types of power have been emphasized: position power and personal power. Position power is dependent on formal position within the hierarchy, is organizationally derived and is external to the manager himself or herself. Personal power on the other hand depends largely on the traits and behaviour of the individual manager, thus depends on the supervisor exercising it, and is internally mediated. This basic distinction between position and personal power ties in very much with the framework of the proposed model of managerial power.

\section{The medium of managerial power}

It should be emphasized that it is not easy to separate the medium of managerial power from the management power base, since the medium used by a manager is part and parcel of the individual's power base. If a distinction can be made, it would probably be that the power base of a manager reflects psychological intent as it were, while the medium is the actual method chosen to express this power.

A useful typology of managerial power is that of French and Raven ${ }^{8}$ who propose five types of power: reward, coercive, legitimate, expert and referent.

This typology is useful in highlighting that the major means available for the expression of managerial power reside either within the manager himself, as in referent and expert power; or within the organizational situation, as in reward, coercive and legitimate power. It should not be forgotten however, that control of the medium of power is not wholely within the hands of the manager. The manager is able to mediate reward and coercive power, but to some extent mediation of the other three types of power lies with the subordinate, in that these depend for their effectiveness on the subordinates' perception of the characteristics of their supervisors and the legitimacy of the authority structure. The fact that power lies with the subordinate to some extent highlights the importance of the employee in the model of managerial power and so introduces the next element of the model.

\section{The bases of employee compliance}

Managers have no power without their subordinates' compliance with their power, and this means in effect that employees themselves have considerable power. Patchen ${ }^{2}$ speaks of the power of the lowerarchy and suggests that there are at least three forms of this power: information control; performance of important organizational functions; and power through belonging to powerful groups. Thus the subordinate has considerable power in determining what information he allows to flow back to his manager; how well, or even whether, he will perform certain critical tasks; and how much power he is able to exhibit in terms of the groups of which he is a member.

There are two major viewpoints of the employee response to managerial power: a sociological one; and a psychological one. The sociological viewpoint sees the employee as part of a community or of a group, to whom work and the organization are merely value or interest elements of a larger total set of life or society values. Thus the key concern is how much of a part work satisfaction plays in total life satisfaction of the individual, and this is considered to be very much a function of wider society and group structures. The sociological viewpoint has been extremely valuable in its highlighting of the changes in society and environment which have brought a growing challenge to managerial power.

The psychological viewpoint on the other hand looks much closer at the individual, his work motivation, job satisfaction, and the type of psychological contract he considers as having been made between himself and the organization. Some of the more radical sociologists (e.g. Clegg \& Dunkerley', and Hofstede ${ }^{19}$, point to an extremely wide difference between these two viewpoints, suggesting that the psychological viewpoint has deliberately overlooked socio-political factors, and concentrated upon a narrow limited set of individual variables. It is considered to be an important contribution of the proposed model of managerial power that both sociological and psychological variables are taken into account and together form the basis for an adequate conception of managerial power.

\section{The psychological contract}

The term 'psychological contract' first appeared in the writing of Argyris " and Levinson ${ }^{12}$ referring to the informal contract employees divised to satisfy their needs in the organization. The psychological contract arose in that employees agreed on an informal basis to give high output or whatever else management was expecting, in return for management agreeing to respect the norms of this informal contract, which employees developed to fit individual needs. Argyris argued that this psychological contract was sufficiently important to be considered as dominating the employee - management relationship.

The key implication of the psychological contract is that managerial power exists only to the extent that the employee's psychological contract is honoured in the power situation between manager and subordinate.

The model of the psychological contract included in Fig. 1 is that of Etzioni ${ }^{13}$. This is a relatively simple framework, but suitable for use since it focusses both on the type of power utilized in the organization, and also on the type of employee response to this power in terms of involvement in the organization.

In terms of Etzioni's model the managerial input to the psychological contract is in terms of type of power or authority utilized, while the employee input to the contract is in terms of degree of involvement in the organization. Etzioni distinguishes three types of organizations on the basis of the type of power or authority that they utilize: 
- Coercive organizations which attempt to win employee involvement through the use of pure coercive power.

- Utilitarian organizations which attempt to elicit employee involvement through the exchange of economic rewards for organizational performance.

- Normative organizations that attempt to elicit involvement primarily on the basis of normative rewards, when the opportunity to perform in the organization comes to be intrinsically valued.

In addition Etzioni distinguishes three types of involvement of organizational members, as follows:

- Alienated: In this type of involvement the employee is in no way psychologically involved with the organization, and remains with the organization only because he is forced to do so.

- Calculative: This type of involvement is essentially a limited one, in that the employee is essentially involved in the organization only to the extent of doing a 'fair day's work for a fair day's pay'. He is a member of the organization purely on the basis of what he receives out of it in terms of economic rewards, and is prepared to give very little should these rewards cease.

- Moral: This type of involvement implies that the employee intrinsically values the mission of the organization and his job within it, and he performs in the organization primarily because he values doing so.

It is an implication of Etzioni's writings that the typical direction of the power in the psychological contract is from organization to employee and from manager to subordinate. In other words, that typically the type of organization authority utilized determines the type of involvement an employee will have with that organization. It should be noted however, that the psychological contract could just as easily operate in the other direction with a particular type of employee involvement resulting in a particular type of managerial power being utilized. For example, a manager who might normally tend to make use of coercive power, on finding that a new group of employees he had been asked to supervise were extremely committed to the organization, might well discover that the use of normative power would be quite sufficient and indeed far more effective. For this reason it is important to emphasize the dynamic nature of the psychological contract and the continual restatement of the balance between participants that takes place.

\section{Conclusion}

In this article an attempt was made to extend the earlier analysis of managerial power at the macro-level by including a focus on the inter-personal power relationship between manager and subordinate. It makes sense to briefly sum up the major implications of the ground that has been covered. Firstly the model has emphasized that the relationship between manager and employee can best be seen in terms of a balance or exchange conception and that this exchange is well expressed in terms of a 'psychological contract' between the two parties. It has further been suggested that the extent of managerial power is a function of the degree to which the terms of the psychological contract are seen to be honoured by management and employees, that is, in terms of the degree of consonance of management and employee perceptions in the psychological contract. It has also been shown that the psychological contract is a dynamic entity in which a close interaction occurs between the type of power the manager uses and the type of response the employee gives. While the psychologists have enabled us to understand a great deal more about the processes which operate in this psychological contract, the sociologists have provided a valuable wider viewpoint by pointing to the need to view the psychological contract within a societal context.

In the final article in this series on managerial power an attempt will be made to integrate the organization compensation system into the model of managerial power. It is important to be able to do this since compensation is probably the area in which management has its greatest opportunity of exercising power. This opportunity is a result of the extreme importance of compensation to employees and the relative ease with which it can be manipulated by management.

\section{References}

1. TEMPLER, A.J. A model of managerial power in the organization. S. Afr. J. Bus. Mgmt., 10, 1979, pp $107-111$.

2. PATCHEN, M. The locus and basis of influence on organisation decisions. Org. Beh. Hum. Perf., 11, 1974, pp 195_1221.

3. TEDESCHI, J.T. Perspectives in Social Power. Aldine Publishing Co., Chicago, 1974, pp $100-168$.

4. JACKSON, J.H. \& MORGAN, C.P. Organisation Theory. Prentice-Hall, Englewood Cliffs, New Jersey, 1978, pp 257-267.

5. POLLARD, W.E. \& MITCHELL, T.R. Decision theory analysis of social power. Psychol. Bull., 78, 1972, pp 433-446.

6. NATEMEYER, W.E. An empirical investigation of the relationships between leader behaviour, leader power bases, and subordinate performance and satisfaction. Unpublished PhD Dissertation, University of Houston, 1975.

7. SHETTY, Y.K. Managerial power and organizational effectiveness. J. Mgmt Studies, 15, 1978, pp $176-186$.

8. FRENCH, J.R.P. \& RAVEN, B. The bases of social power. In: Group Dynamics, (eds) Cartwright, D. \& Zander, A., Harper \& Row, New York, 1968, pp 259-269.

9. CLEGG, S. \& DUNKERLEY, D. Critical Issues in Organizations. Routledge and Kegan Paul, London, 1977, pp 3-40.

10. HOFSTEDE, G. Humanisation of Work. European Institute for Advanced Studies in Management, Brussels, Working Paper $77-116,1976$.

11. ARGYRIS, C. Understanding Organizational Behaviour. Dorsey Press, Homewood Illinois, 1960, pp 6-120.

12. LEVINSON, H. et al. Men, Management and Mental Health. Harvard University Press, Cambridge, Massachusetts, 1962, pp $90-140$.

13. ETZIONI, A. A basis for comparative analysis of complex organizations. In: A Sociological Reader on Complex Organizations, (ed) Etzioni, A., Holt, Rinehart \& Winston Inc., New York, 1969, pp $59-76$. 